\title{
The influence of the diamond wheel grinding process on the selected properties of boron nitride dispersion in cemented carbide (BNDCC) composites
}

\author{
Barbara Staniewicz-Brudnik $^{1}$ - Małgorzata Karolus ${ }^{1}$ (D) - Elżbieta Bączek ${ }^{1}$. \\ Grzegorz Skrabalak $^{1} \cdot$ Jolanta Laszkiewicz-Lukasik ${ }^{1}$
}

Received: 10 July 2017 / Accepted: 2 November 2017 / Published online: 10 November 2017

(C) The Author(s) 2017. This article is an open access publication

\begin{abstract}
The paper presents the results of research into the influence of the process of grinding boron nitride dispersed cemented carbide (BNDCC) composite using diamond wheel with vitrified bond on the selected properties of this composite. Cutting tools of BNDCC composite were manufactured using several machining operations. At first stage, they were EDM (electrical discharge machining) wire cut from tablets and later on ground with diamond wheels (which removed the "white layer" produced by EDM cutting). Rake and flank faces of prepared cutting tools were examined by microscopic, topographic, and surface analytical techniques before and after grinding. The paper presents comparative results of BNDCC tools and tools made of H10S cemented carbide. Values of the grinding efficiency parameters, $Q_{w}$, average material removal rate of grinding, $Q_{w}^{\prime}$, average material removal rate per unit active grinding wheel for the two materials, were similar, indicating an insignificant effect of introduction of the harder BN phase into WCCo on
\end{abstract}

Małgorzata Karolus

karolus@us.edu.pl

Barbara Staniewicz-Brudnik

barbara.brudnik@ios.krakow.pl

Elżbieta Bączek

elzbieta.baczek@ios.krakow.pl

Grzegorz Skrabalak

grzegorz.skrabalak@ios.krakow.pl

Jolanta Laszkiewicz-Łukasik

jolanta.laszkiewicz@ios.krakow.pl

1 Institute of Advanced Manufacturing Technology, Wroclawska 37A, 30-011 Cracow, Poland these parameters. $R_{a}$, surface roughness of flank face, was $0.040 \mu \mathrm{m}$ for BNDCC composite and $0.51 \mu \mathrm{m}$ for H10S after grinding, compared to 1.14 and $1.30 \mu \mathrm{m}$, respectively, before grinding. WC residual stress measurements in the flank faces of BNDCC tools were inconclusive; in the flank faces, the stresses were compressive, decreasing, e.g., from -230 to $-1670 \mathrm{MPa}$ after grinding. For the H10S tools, there was no comparable effect. The results also indicate that the vitrified bonded diamond abrasive wheel used is effective in grinding WCCo and BNDCC cutting tools.

Keywords Sintering $\cdot$ Composites $\cdot \mathrm{X}$-ray methods $\cdot$ Wear resistance $\cdot$ Glass ceramics

\section{Introduction}

When machining abrasion-resistant materials such as composites of metal-ceramic matrix with non-ferrous metals (in particular aluminum and titanium) and its alloys reinforced with hard particles and composites of plastics reinforced with glass fibers, cemented carbide tools are being replaced by considerably more expensive, but more abrasion-resistant polycrystalline diamond $(P C D)$ tools [1-3]. The wear resistance of cemented carbides can be significantly increased, while retaining their high fracture toughness, by replacing part of the carbide phase with cubic boron nitride grains as a dispersive phase. This composite can be produced with method of pulse plasma sintering (PPS) [4-6]. This method allows to carry out the sintering process at a lower temperature and in shorter time than the conventional methods for preparing WCCo composite. Composites such as cubic boron nitride dispersed in cemented carbide (BNDCC) are 
Table 1 Properties of the ceramic binder used for diamond grinding wheels (results are averaged values of five grinding attempts)

\begin{tabular}{ll}
\hline Binder properties & "Ba23 bis" binder \\
\hline Wettability to substrate graphite $[\mathrm{deg}]$ & $38 \pm 2$ \\
Microhardness [GPa] & $5.9 \pm 0.12$ \\
Flexural strength $[\mathrm{MPa}]$ & $100 \pm 2.71$ \\
Young modulus $[\mathrm{MPa}]$ & $89 \pm 3.1$ \\
TCE coefficient $\left[10^{-6} 1 / \mathrm{deg}\right]$ & $4.9 \pm 0.06$ \\
\hline
\end{tabular}

characterized by higher hardness, wear resistance, the same high resistance to cracking than sintered (cemented) carbide, and higher coefficient of thermal conductivity which improved working condition for tool by lowering the temperature in cut zone. The grinding process of BNDCC composites required special diamond abrasive tools containing ceramic (vitrified) binders [7, 8] dedicated to processing of these materials.

The effectiveness of using a vitrified bond indicates the selection of properties such as good wetting of the diamond by binder [9], similar or identical values of coefficient of the linear thermal expansion of binder and diamond, high microhardness, and high Young modulus of binder. These properties induced the abrasive grains in the ring working up to selfsharpening as well as preventing from adhesion to the workpiece during grinding process. These properties are

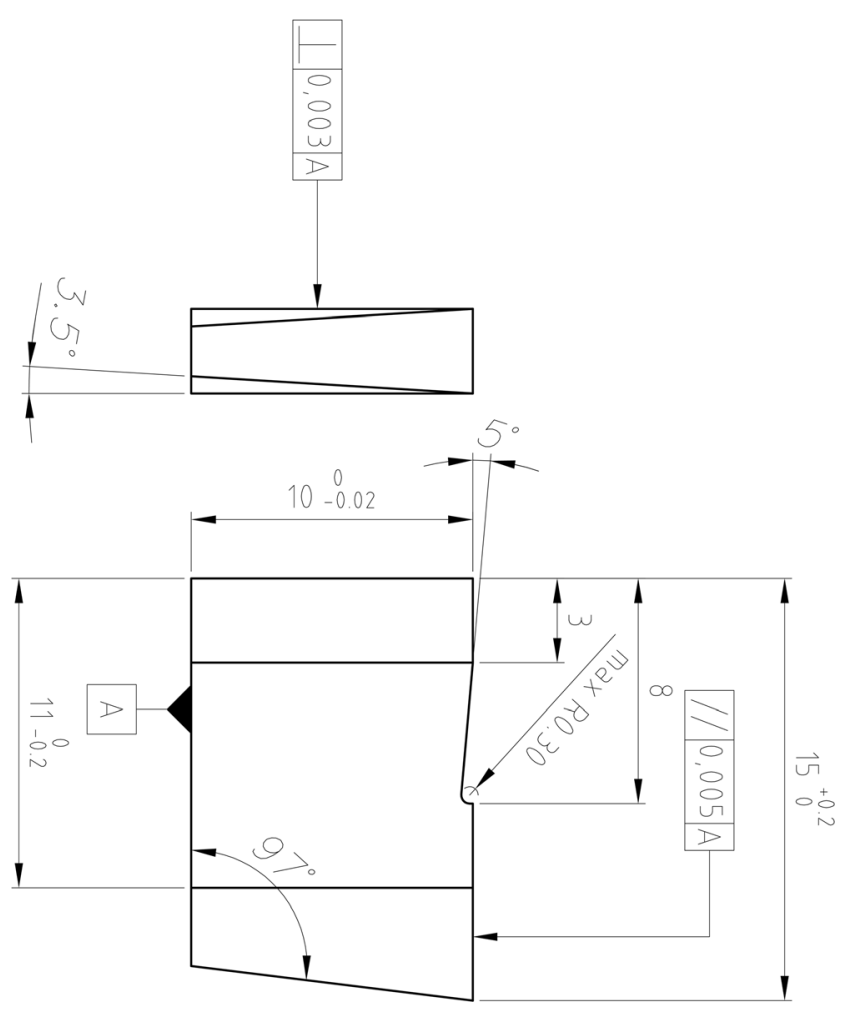

Fig. 1 The scheme of edge of BNDCC composite
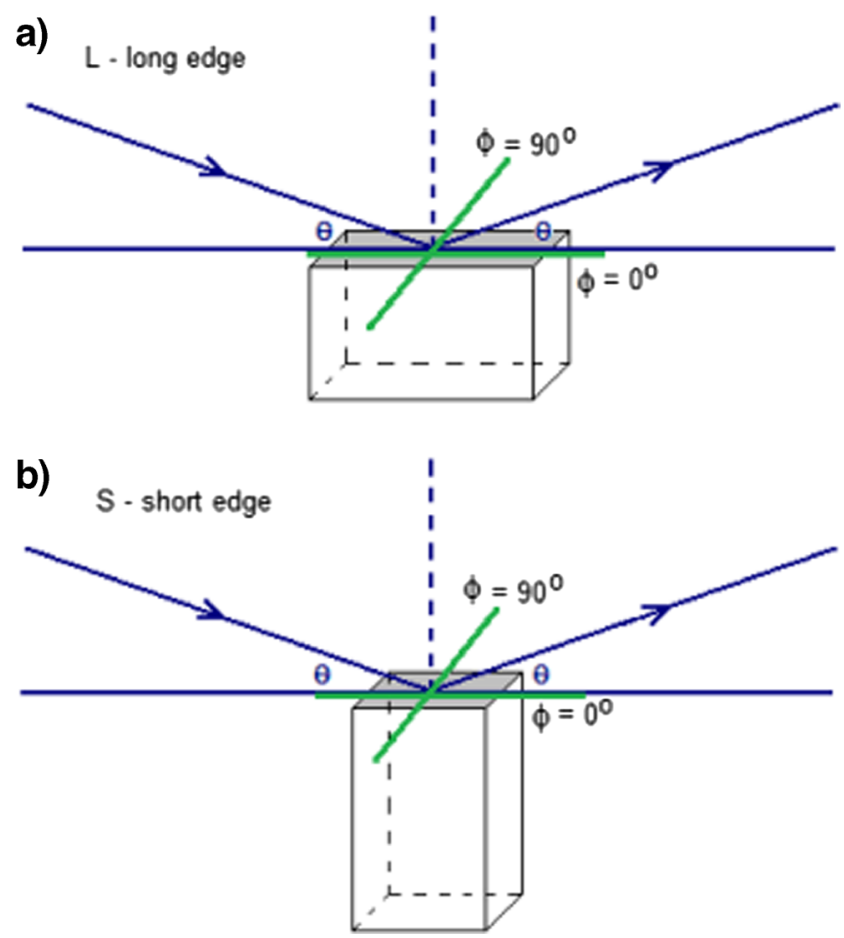

Fig. 2 The scheme of the measurement geometry of testing samples: a long edge (rake face), $L$, and $\mathbf{b}$ short edge (flank face), $S$

characterized by a ceramic binder based on $\mathrm{Al}_{2} \mathrm{O}_{3}-\mathrm{SiO}_{2}-$ $\mathrm{Na}_{2} \mathrm{O}-\mathrm{B}_{2} \mathrm{O}_{3}-\mathrm{BaO}$ system glass (Table 1).

Our diamond grinding wheel with ceramic binder in addition to multi-component system glass contained molybdenum disulfide $\mathrm{MoS}_{2}$ and bismuth oxide $\mathrm{Bi}_{2} \mathrm{O}_{3}$. Molybdenum disulfide fulfills the role of a solid lubricant resulting from its layered structure. The S-Mo-S layers formed the loosely packages bonded linked together but at the same time they combined a strong bond with a dominant share of covalent. The role of bismuth oxide was primarily to produce a reinforcing thin submicron film around the diamond grains reinforcing connection with the binder with a binder.

The results of literature and technical catalogues of diamond grinding wheel producers survey show that the diamond grinding tools are characterized by such unique

Table 2 Average parameters $\left(Q_{w}\right.$ and $\left.Q_{w}^{\prime}\right)$ with standard deviation of the grinding process of BNDCC composite by $D 25$ grinding wheel

\begin{tabular}{clll}
\hline BNDCC & $\begin{array}{l}\text { Working } \\
\text { engagement } \\
g[\mathrm{~mm} / \text { double } \\
\text { stroke of the } \\
\text { table] }\end{array}$ & $\begin{array}{l}\text { Average material } \\
\text { removal rate of } \\
\text { grinding } Q_{w} \times 10^{-2} \\
{\left[\mathrm{~mm}^{3} / \mathrm{s}\right]}\end{array}$ & $\begin{array}{l}\text { Average material } \\
\text { removal rate per } \\
\text { unit active grinding } \\
\text { wheel } Q_{w}^{\prime} \times 10^{-2} \\
{\left[\mathrm{~mm}^{3} / \mathrm{mm} \mathrm{s}\right.}\end{array}$ \\
\hline $\begin{array}{c}\text { Rake face } \\
\text { area }\end{array}$ & 0.01 & $1.032 \pm 0.063$ & $0.103 \pm 0.006$ \\
$\begin{array}{c}\text { Flank face } \\
\text { area }\end{array}$ & 0.02 & $2.172 \pm 0.322$ & $0.217 \pm 0.032$ \\
\hline
\end{tabular}


Table 3 Average parameters $\left(Q_{w}\right.$ and $\left.Q_{w}^{\prime}\right)$ with standard deviation of the grinding process of H10S composite by $D 25$ grinding wheel

\begin{tabular}{clll}
\hline H10S & $\begin{array}{l}\text { Working } \\
\text { engagement } \\
g[\mathrm{~mm} / \text { double } \\
\text { stroke of the } \\
\text { table }]\end{array}$ & $\begin{array}{l}\text { Average material } \\
\text { removal rate of } \\
\text { grinding } Q_{w} \times 10^{-2} \\
{\left[\mathrm{~mm}^{3} / \mathrm{s}\right]}\end{array}$ & $\begin{array}{l}\text { Average material } \\
\text { removal rate per unit } \\
\text { active grinding wheel } \\
Q^{\prime}{ }_{w} \times 10^{-2}\left[\mathrm{~mm}^{3} /\right. \\
\mathrm{mm} \mathrm{s}]\end{array}$ \\
\hline $\begin{array}{c}\text { Rake face } \\
\text { area }\end{array}$ & 0.01 & $1.094 \pm 0.150$ & $0.109 \pm 0.0150$ \\
$\begin{array}{c}\text { Flank face } \\
\text { area }\end{array}$ & 0.02 & $2.226 \pm 0.26$ & $0.223 \pm 0.026$ \\
\hline
\end{tabular}

properties. Among others, the most commonly used concerns are as follows: volume fraction (ranging from $\mathrm{C} 120$ to C480); structure, hardness and porosity; and a considerable capacity for both self-sharpening and shaping by the conventional method.

Presented research focuses on the impact of grinding process (with diamond wheels built with dedicated ceramic binder) on residual stresses of their own flank and rake face area of machined cutting tools of H10S and BNDCC composites.

\section{Materials}

Manufacturing of BNDCC cutting tools used in the study includes several shaping stages and machining processes. At first stage, raw material (supplied by the Warsaw University of Technology in the form of tablets of $4.1 \mathrm{~mm}$ thick with diameter of $19 \mathrm{~mm}$ ) are machined with wired electrodischarge cutting (WEDM) - for surface waviness smoothing and cutting of tool geometry leaving $\sim 0.2 \mathrm{~mm}$ in each dimension for finishing operations. The second stage of machining concerns grinding of prepared sub-products: flat side surfaces grinding and grinding of tool edges.

For WEDM process, the wire-cutting machine of the Institute design-EDM-EWIOS40 — was used. WEDM

Table 4 Average parameters $\left(Q_{w}\right.$ and $\left.Q_{w}^{\prime}\right)$ with standard deviation of the grinding process of BNDCC composite by $D 46$ grinding wheel

\begin{tabular}{clll}
\hline BNDCC & $\begin{array}{l}\text { Working } \\
\text { engagement } \\
g[\mathrm{~mm} / \text { double } \\
\text { stroke of the } \\
\text { table] }\end{array}$ & $\begin{array}{l}\text { Average material } \\
\text { removal rate of } \\
\text { grinding } Q_{w} \times 10^{-2} \\
{\left[\mathrm{~mm}^{3} / \mathrm{s}\right]}\end{array}$ & $\begin{array}{l}\text { Average material } \\
\text { removal rate per } \\
\text { unit active grinding } \\
\text { wheel } Q^{\prime}{ }_{w} \times 10^{-2} \\
{\left[\mathrm{~mm}^{3} / \mathrm{mm} \mathrm{s}^{2}\right.}\end{array}$ \\
\hline $\begin{array}{c}\text { Rake face } \\
\text { area }\end{array}$ & 0.01 & $1.028 \pm 0.145$ & $0.103 \pm 0.0145$ \\
$\begin{array}{c}\text { Flank face } \\
\text { area }\end{array}$ & 0.02 & $2.11 \pm 0.249$ & $0.211 \pm 0.025$ \\
\hline
\end{tabular}

Table 5 Average parameters $\left(Q_{w}\right.$ and $\left.Q_{w}^{\prime}\right)$ with standard deviation of the grinding process of H10S composite by $D 46$ grinding wheel

\begin{tabular}{clll}
\hline H10 & $\begin{array}{l}\text { Working } \\
\text { engagement } \\
g[\mathrm{~mm} / \text { double } \\
\text { stroke of the } \\
\text { table }]\end{array}$ & $\begin{array}{l}\text { Average material } \\
\text { removal rate of } \\
\text { grinding } Q_{w} \times 10^{-2} \\
{\left[\mathrm{~mm}^{3} / \mathrm{s}\right]}\end{array}$ & $\begin{array}{l}\text { Average material } \\
\text { removal rate per } \\
\text { unit active grinding } \\
\text { wheel } Q^{\prime} \times 10^{-2} \\
{\left[\mathrm{~mm}^{3} / \mathrm{mm} \mathrm{s}\right]}\end{array}$ \\
\hline $\begin{array}{c}\text { Rake face } \\
\text { area }\end{array}$ & 0.01 & $1.098 \pm 0.087$ & $0.110 \pm 0.009$ \\
$\begin{array}{c}\text { Flank face } \\
\text { area }\end{array}$ & 0.02 & $2.178 \pm 0.212$ & $0.218 \pm 0.021$ \\
\hline
\end{tabular}

process was performed with brass galvanized wire of $0.25 \mathrm{~mm}$ diameter, under the following electrical conditions: pulse on/off $4 \mu \mathrm{s} / 80 \mu \mathrm{s}$, discharge current $150 \mathrm{~A}$, discharge voltage $160 \mathrm{~V}$.

The same machining processes were applied for manufacturing of reference samples of H10S cemented carbide. For the test grinding of the rake and flank face area of BNDCC (Fig. 1) and H10S composites, diamond grinding wheels were made as follows: type 6A2 100x10x4 D46/D25 Ba 23b, with a reduced concentration of diamond, at $c 75$, containing uncoated diamond grain manufactured by the Lands company, with a grit size of $D 46$, type $L S 120(38-45 \mu \mathrm{m})$ and $D 25$, type $L S 600 F(20$ $30 \mu \mathrm{m}$ ), and an amorphous binder from the $\mathrm{Al}_{2} \mathrm{O}_{3}-\mathrm{SiO}_{2}-$ $\mathrm{Na}_{2} \mathrm{O}-\mathrm{B}_{2} \mathrm{O}_{3}-\mathrm{BaO}$ system.

\section{Methods}

The grinding process was carried out on a $4 A M$ grinding machine manufactured by FUM Pabianice and equipped with an attachment for low speed-grinding and cooling by means of spraying a $2 \%$ water solution of PGA SYNKON coolant concentrate. The fixed and variable parameters of the grinding process were established basing on the results of previous studies [8].

The following variable parameters were adopted:

- A grinding depth of 0.02: $0.01 \mathrm{~mm} /$ double stroke

- A diamond grain granulation of D46, D25

- Five repetition tests (5)

The following fixed parameters were adopted:

- The test stand

- The peripheral speed of grinding wheel vs $4.8 \mathrm{~m} / \mathrm{s}$

- The wheel's characteristics and dimensions: type 642 $100 \times 10 \times 4$

- The type of feed coolant: Synkon

- The coolant method: flooding 
Fig. 3 The X-ray diffraction patterns obtained for BNDCC sample for the different measurement geometries - long edge (rake face), $L$, and short edge (flank face), $S-\mathbf{a}$ before grinding and $\mathbf{b}$ after grinding a)

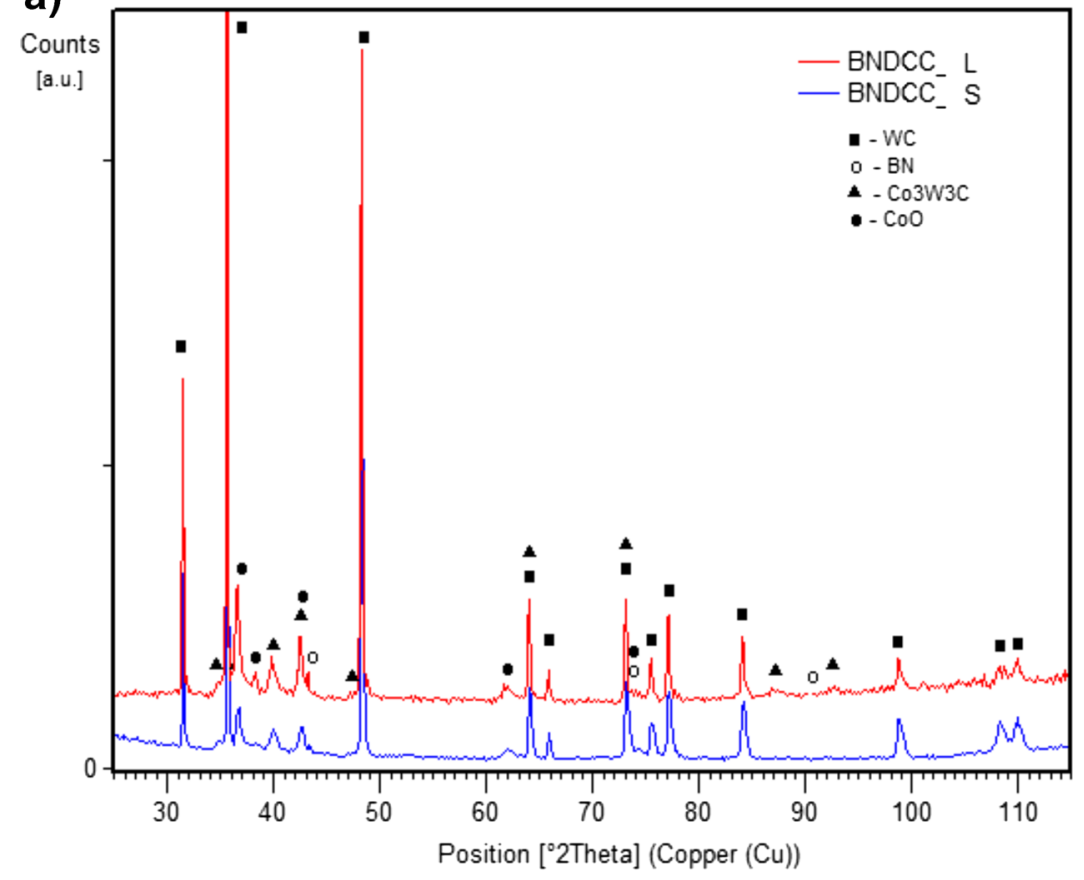

b)

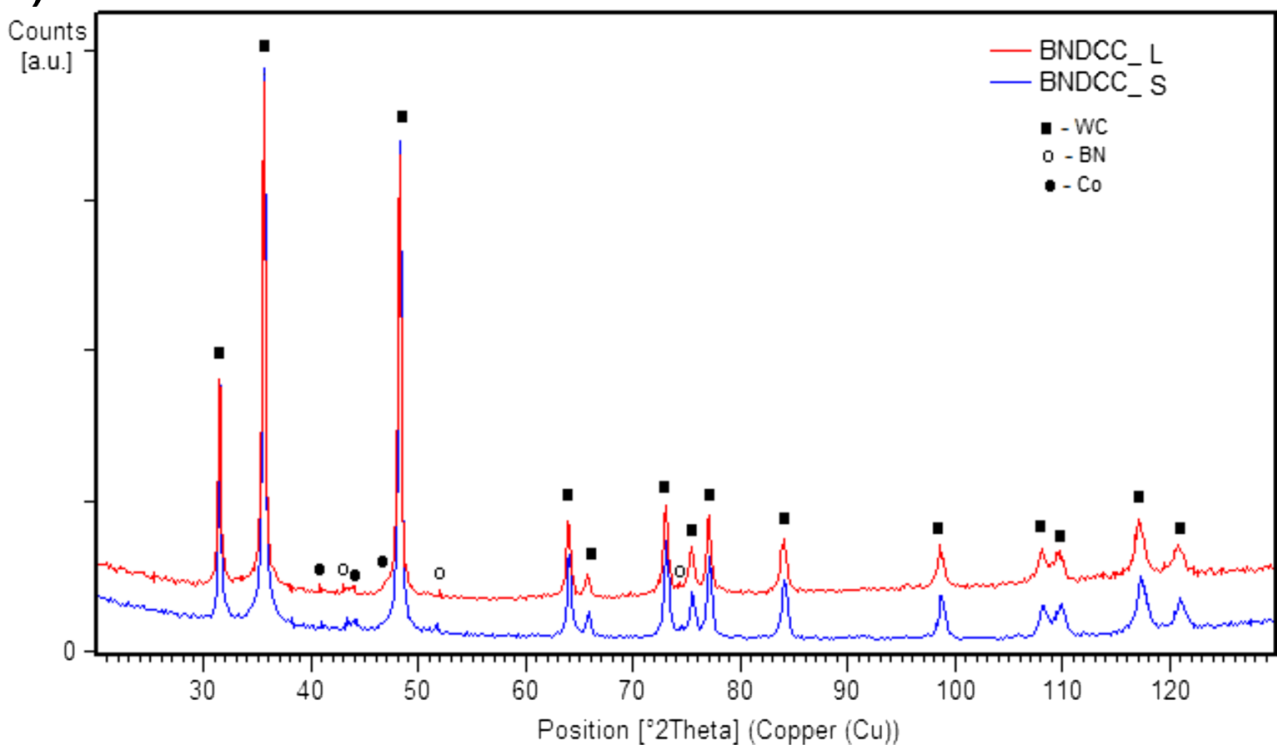

Table 6 Results of the phase analyses of the BNDCC sample before and after grinding

\begin{tabular}{llllll}
\hline & Space group & Crystal system & $\begin{array}{l}\text { Unit cell parameters } \\
\mathrm{a} / \mathrm{b} / \mathrm{c}[\AA]\end{array}$ & Before grinding & After grinding \\
\hline $\mathrm{WC}$ & $\mathrm{P}-6 \mathrm{~m} 2$ & Hexagonal & $2.9063 / 2.8375$ & $\mathrm{x}$ & $\mathrm{x}$ \\
$\mathrm{BN}$ & $\mathrm{F}-43 \mathrm{~m}$ & Cubic & 3.6159 & $\mathrm{x}$ & $\mathrm{x}$ \\
$\mathrm{Co}_{3} \mathrm{~W}_{3} \mathrm{C}$ & $\mathrm{Fd} 3 \mathrm{~m}$ & Cubic & 11.1120 & $\mathrm{x}$ & - \\
$\mathrm{CoO}$ & $\mathrm{Fm}-3 \mathrm{~m}$ & Cubic & 4.2400 & $\mathrm{x}$ & - \\
$\mathrm{Co}$ & $\mathrm{P} 63 \mathrm{mmc}$ & Hexagonal & $2.5054 / 4.0893$ & - & $\mathrm{x}$ \\
\hline
\end{tabular}


Fig. 4 The X-ray diffraction patterns obtained for $\mathrm{H} 10 \mathrm{~S}$ sample before grinding for the different measurement geometries - long edge (rake face), $L$, and short edge (flank face), $S-\mathbf{a}$ before grinding and $\mathbf{b}$ after grinding a)

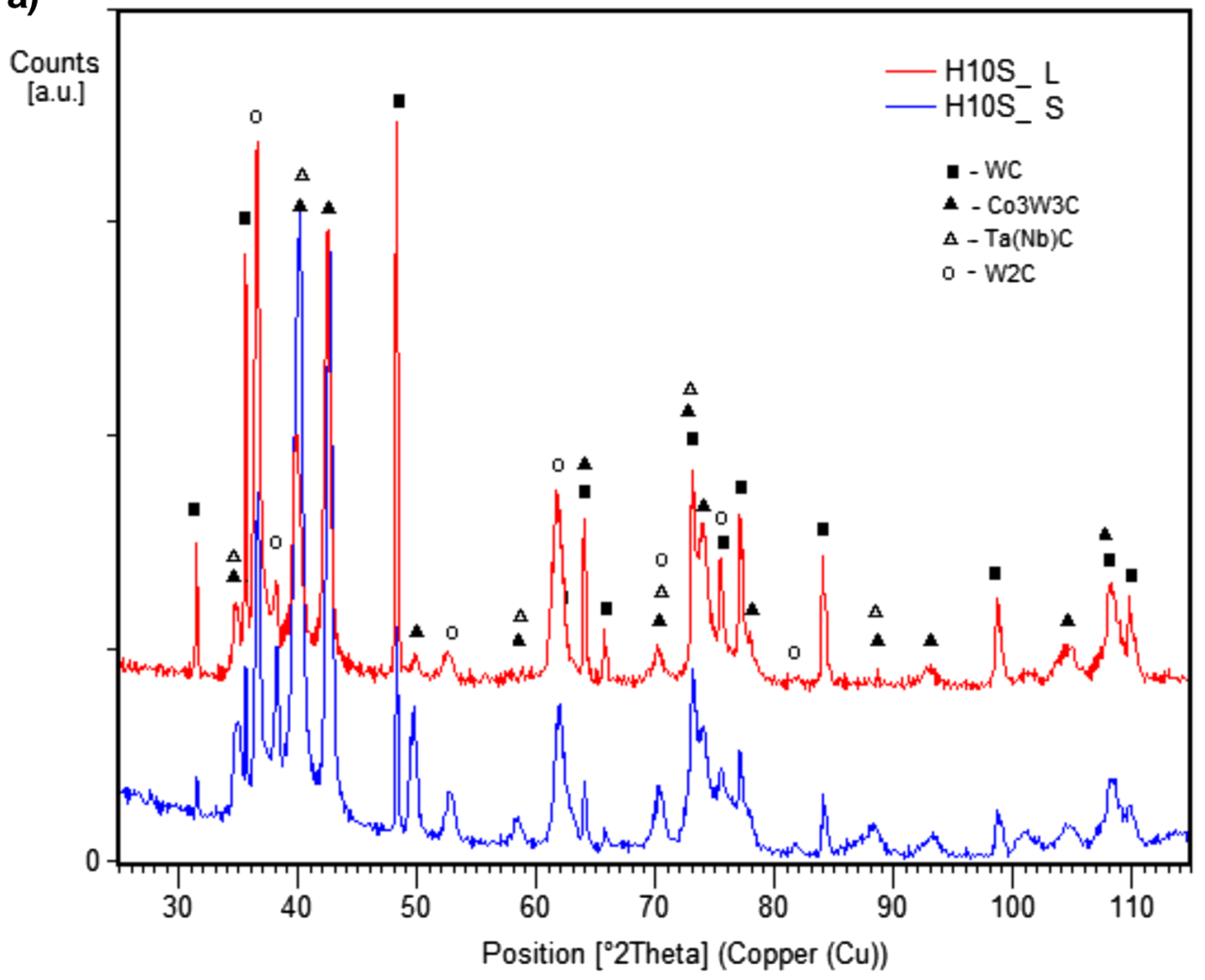

b)

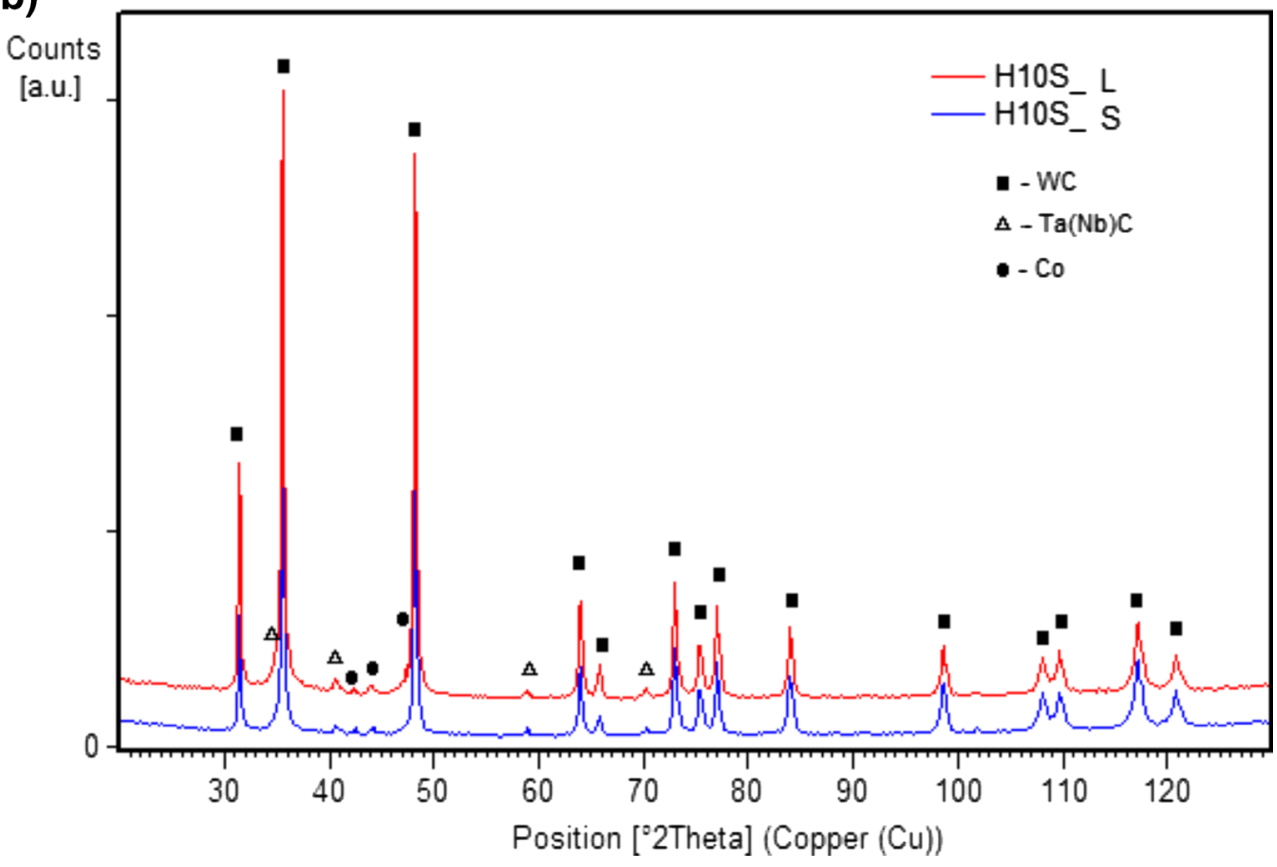

- A testing system of $24 \mathrm{~s}$ for the rake face area and for $30 \mathrm{~s}$ for the flank face area

- The concentration of the diamond: $c 75 \%$

Before and after the grinding process, samples were analyzed using the XRD method and the phase composition was determined. After which, the residual stress along the rake and flank face area of the composite was determined.

The weight of the material removed and the height of the wheel were measured. The volume of abraded material, the material removal rate for the grinding, by volume, 
Table 7 Results of the phase analyses of the H10S sample before and after grinding

\begin{tabular}{llllll}
\hline & Space group & Crystal system & $\begin{array}{l}\text { Unit cell parameters } \\
\mathrm{a} / \mathrm{b} / \mathrm{c}[\AA]\end{array}$ & Before grinding & After grinding \\
\hline $\mathrm{WC}$ & $\mathrm{P}-6 \mathrm{~m} 2$ & Hexagonal & $2.9063 / 2.8375$ & $\mathrm{x}$ & $\mathrm{x}$ \\
$\mathrm{W}_{2} \mathrm{C}$ & $\mathrm{Pbcn}$ & Hexagonal & $4.7280 / 6.0090 / 5.1930$ & $\mathrm{x}$ & - \\
$\mathrm{Co}_{3} \mathrm{~W}_{3} \mathrm{C}$ & $\mathrm{Fd} 3 \mathrm{~m}$ & Cubic & 11.1120 & $\mathrm{x}$ & - \\
$\mathrm{Ta}(\mathrm{Nb}) \mathrm{C}$ & $\mathrm{Fm}-3 \mathrm{~m}$ & Cubic & 4.4500 & $\mathrm{x}$ & $\mathrm{x}$ \\
$\mathrm{Co}$ & $\mathrm{P} 63 \mathrm{mmc}$ & Hexagonal & $2.5054 / 4.0893$ & - & $\mathrm{x}$ \\
\hline
\end{tabular}

namely $Q_{w}$, and the material removal rate for the grinding, per unit of active grinding wheel, $Q^{\prime}{ }_{w}$, were calculated. The weight of the samples was measured before and after each grinding process with a laboratory scale with a measurement accuracy of up to $0.001 \mathrm{~g}$. The height of the wheel before and after each test was measured with electronic calipers with accuracy of $0.01 \mathrm{~mm}$. Measurements of the surface topography of the BNDCC composite and the $\mathrm{H} 10 \mathrm{~S}$ reference sample $\mathrm{H} 10 \mathrm{~S}$ were taken using a TOPO $01 \mathrm{olvP}$ modular profilometer of IAMT production [10].

Topography of surfaces was measured before attempting the grinding and after its completion. The values of the surface roughness parameters $\left(R_{\mathrm{a}}, R_{\mathrm{z}}, R_{\mathrm{t}}\right)$ and the edge roughness parameters roughness were calculated. The microscopic observation of the flank and rake face area was carried out on a scanning electron microscope (SEM) before and after the grinding process.

The X-ray diffraction patterns were obtained using a PANalytical Empyrean diffractometer with copper radiation $(\lambda \mathrm{Cu} \mathrm{K} \alpha=1.5418 \AA)$. The phase analysis was conducted using ICDD (PDF-4+ 2014) files. The refinement of the unit cell parameters for the studied materials was performed using the Rietveld refinement [11] with the HighScore Plus PANalytical software. The XRD measurements were taken for both surfaces, namely, the rake face (L) and the edge area (S), of the BNDCC and the H10S reference material before and after grinding. The scheme

Table 8 Results of residual stress calculations $(\sigma)$ obtained for WC phase (201) in the BNDCC sample for long edge (rake face), L, and short edge (flank face), $\mathrm{S}$

\begin{tabular}{llll}
\hline Residual stress & & \multicolumn{2}{l}{$\sigma[\mathrm{MPa}]$} \\
BNDCC & & WC (201) & \\
\cline { 3 - 4 } & Edge & $0^{\circ}$ & $90^{\circ}$ \\
\hline Before grinding & $\mathrm{L}$ & 6302 & -50 \\
& $\mathrm{~S}$ & -227 & -319 \\
After grinding & $\mathrm{L}$ & -406 & 301 \\
& $\mathrm{~S}$ & -1673 & -799 \\
\hline
\end{tabular}

of geometry measurement of the investigated samples is presented in Fig. 2.

The X-ray measurements for the determination of residual stress were performed using an Empyrean PANalytical diffractometer with copper radiation $(\lambda \mathrm{Cu}$ $\mathrm{K} \alpha=1.5418 \AA$ ) at two $\varphi$ angle directions, $0^{\circ}$ and $90^{\circ}$, parallel with, and perpendicular to, the X-ray beam. The $\sin ^{2} \psi$ method was used in order to determine the residual stresses [14]. The Poisson coefficient $(\nu)$ and Young modulus $(E)$ values characterizing the main WC phase, which were used during performed analyses, are $534.4 \mathrm{GPa}$ and 0.22 , respectively [15].

Microstructure studies of the BNDCC composite flank and rake face area of were conducted before and after the grinding process. An SEM-LV 6064 JEOL scanning electron microscope was used under the following conditions:

- An accelerating voltage of $10 \mathrm{kV}$

- The distance from the pole 10

- The character of the backscattered electrons image (BES)

\section{Results and discussion}

The results of the grinding process using a $D 46$ and $D 25$ diamond wheel containing the newly developed bond and

Table 9 Results of residual stress calculations $(\sigma)$ obtained for WC phase (201) and H10S sample for the long edge (rake face), L, and the short edge (flank face), $\mathrm{S}$

\begin{tabular}{llll}
\hline Residual stress & & \multicolumn{1}{c}{$\sigma[\mathrm{MPa}]$} & \\
H10S & & WC (201) & \\
\cline { 3 - 4 } & & $\varphi=0^{\circ}$ & $\varphi=90^{\circ}$ \\
\hline Before grinding & $\mathrm{L}$ & -2273 & -3756 \\
& $\mathrm{~S}$ & -1388 & -2205 \\
After grinding & $\mathrm{L}$ & -570 & -1577 \\
& $\mathrm{~S}$ & -1005 & -1571 \\
\hline
\end{tabular}


Table 10 Profile parameters of the flank face of BNDCC composite before and after grinding process

\begin{tabular}{llllll}
\hline Profile parameters & \multicolumn{2}{c}{ Before grinding process } & & \multicolumn{2}{c}{ After grinding process } \\
\cline { 2 - 3 } \cline { 6 - 6 } \cline { 6 - 6 } & Average & Accuracy $S$ & & Average & Accuracy $S$ \\
\hline $\mathrm{R}_{\mathrm{a}}[\mu \mathrm{m}]$ & 1.137 & 0.055 & & 0.040 & 0.002 \\
$\mathrm{R}_{\mathrm{v}}[\mu \mathrm{m}]$ & 3.452 & 0.259 & & 0.161 & 0.023 \\
$\mathrm{R}_{\mathrm{z}}[\mu \mathrm{m}]$ & 6.808 & 0.402 & & 0.296 & 0.035 \\
$R_{\mathrm{t}}[\mu \mathrm{m}]$ & 8.426 & 0.823 & & 0.395 & 0.120 \\
\hline
\end{tabular}

operating the tool at a peripheral speed of $4.8 \mathrm{~m} / \mathrm{s}$ are presented in Tables 2, 3, 4, and 5. Presented results are averaged values of five grinding attempts.

Analysis of the results obtained from the tests leads to the conclusion that introducing a harder phase (CBN) to WCCo (BNDCC composite) did not result in significant differences in the grinding efficiency $Q_{w}$ for either the D46 or the D25 grinding wheel at the same value of working engagement. This can be explained by the formation of a solid lubricant (MoS2) in contact with which significantly reduced friction. Because of total material selection, a feed rate of $0.02 \mathrm{~mm} /$ double stroke under this treatment is preferred. The concentration of diamond grain, at $c 75$, which is lower than that of standard diamond wheels, did not have a significant influence on grinding performance. In both cases (grinding with D46 and D25), the self-sharpening phenomenon involving microchunking, providing the formation of new, sharp microedges, was observed. It was explained by a very good quality of ceramic binder that allowed to keep the diamond grains until its self-sharpening.

\subsection{XRD measurements}

The structural analysis conducted on the basis of the Rietveld method leads to obtaining the refined values of the unit cell parameters for identified phases $[12,13]$. The diffraction patterns obtained for the rake face and edge area of the samples show no significant differences in phase composition. The results of the phase analysis of

Table 11 Profile parameters of the edge roughness of BNDCC composite before and after grinding process

\begin{tabular}{llllll}
\hline Profile parameters & \multicolumn{2}{l}{ Before grinding process } & & \multicolumn{2}{l}{ After grinding process } \\
\cline { 2 - 3 } \cline { 6 - 6 } \cline { 5 - 6 } & Average & Accuracy S & & Average & Accuracy S \\
\hline$R_{\mathrm{a}}[\mu \mathrm{m}]$ & 1.082 & 0.097 & & 0.652 & 0.036 \\
$R_{\mathrm{v}}[\mu \mathrm{m}]$ & 3.479 & 0.582 & & 2.776 & 0.362 \\
$R_{\mathrm{z}}[\mu \mathrm{m}]$ & 7.885 & 0.823 & & 4.357 & 0.311 \\
$R_{\mathrm{t}}[\mu \mathrm{m}]$ & 11.267 & 1.314 & & 6.346 & 0.983 \\
\hline
\end{tabular}

Table 12 Profile parameters of the flank face of H10S composite before and after grinding process

\begin{tabular}{llllll}
\hline Profile parameters & \multicolumn{2}{l}{ Before grinding process } & & \multicolumn{2}{c}{ After grinding process } \\
\cline { 2 - 3 } \cline { 5 - 6 } \cline { 5 - 6 } & Average & Accuracy S & & Average & Accuracy S \\
\hline$R_{\mathrm{a}}[\mu \mathrm{m}]$ & 1.299 & 0.097 & & 0.051 & 0.001 \\
$R_{\mathrm{v}}[\mu \mathrm{m}]$ & 4.005 & 0.351 & & 0.195 & 0.012 \\
$R_{\mathrm{Z}}[\mu \mathrm{m}]$ & 7.558 & 0.553 & & 0.364 & 0.016 \\
$R_{\mathrm{t}}[\mu \mathrm{m}]$ & 9.692 & 1.013 & & 0.449 & 0.025 \\
\hline
\end{tabular}

BNDCC sample before grinding are presented in Fig. 3a and Table 6 . The main phases detected in the material are $\mathrm{WC}, \mathrm{BN}, \mathrm{Co}_{3} \mathrm{~W}_{3} \mathrm{C}$, and $\mathrm{CoO}$. The phase analysis performed for the BNDCC sample after the grinding process showed the presence of $\mathrm{WC}, \mathrm{BN}$, and Co phases (Fig. 3b and Table 6). There are no lines for the $\mathrm{Co}_{3} \mathrm{~W}_{3} \mathrm{C}$ and $\mathrm{CoO}$ phases, which indicates that they are only present on the surface of the samples. The X-ray diffraction patterns obtained for both surfaces show no differences.

Figure $4 \mathrm{a}$ presents the diffraction patterns obtained for the rake face and flank face of the reference material H10S before grinding. The $\mathrm{WC}, \mathrm{W}_{2} \mathrm{C}, \mathrm{Co}_{3} \mathrm{~W}_{3} \mathrm{C}$, and $\mathrm{Ta}(\mathrm{Nb}) \mathrm{C}$ solid solution are detected. However, the differences in the intensities of the diffraction lines of the $\mathrm{WC}$ and $\mathrm{W}_{2} \mathrm{C}$ phases, in a range of $35-45^{\circ} 2 \theta$, are observed. This indicates the presence of texture of them in the material. The XRD results show no significant differences in phase composition, either. The results of the phase analysis are presented in the Table 7 . The phase analysis performed for the H10S sample after grinding process showed that only the $\mathrm{WC}, \mathrm{Ta}(\mathrm{Nb}) \mathrm{C}$, and Co phases were present (Fig. $4 \mathrm{~b}$ and Table 7). The X-ray diffraction patterns also show no differences.

There are differences in the amounts of observed phases, which indicates a non-homogenous phase distribution on the studied surfaces.

\subsection{Stress determination}

Values of residual stresses in the BNDCC sample before and after grinding were calculated for $\mathrm{WC}$, the main phase

Table 13 Profile parameters of the edge roughness of H10S composite before and after grinding process

\begin{tabular}{llllll}
\hline Profile parameters & \multicolumn{2}{c}{ Before grinding process } & & \multicolumn{2}{c}{ After grinding process } \\
\cline { 2 - 3 } \cline { 6 - 6 } \cline { 5 - 6 } & Average & Accuracy S & & Average & Accuracy S \\
\hline$R_{\mathrm{a}}[\mu \mathrm{m}]$ & 1.636 & 0.178 & & 0.431 & 0.058 \\
$R_{\mathrm{v}}[\mu \mathrm{m}]$ & 4.525 & 0.597 & & 1.880 & 0.055 \\
$R_{\mathrm{z}}[\mu \mathrm{m}]$ & 10.717 & 1.518 & & 3.292 & 0.463 \\
$R_{\mathrm{t}}[\mu \mathrm{m}]$ & 16.553 & 6.578 & & 5.259 & 1.574 \\
\hline
\end{tabular}




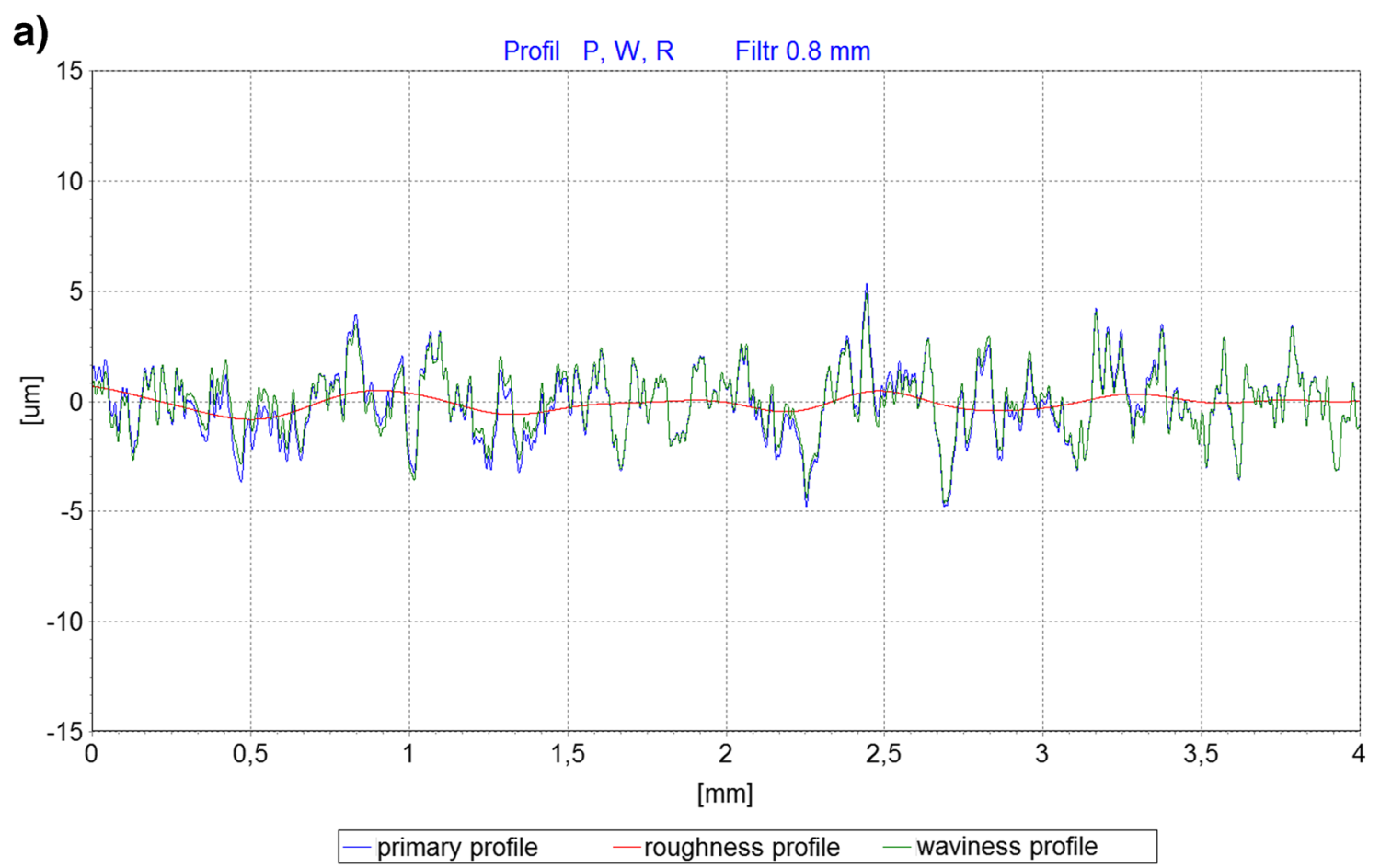

b)

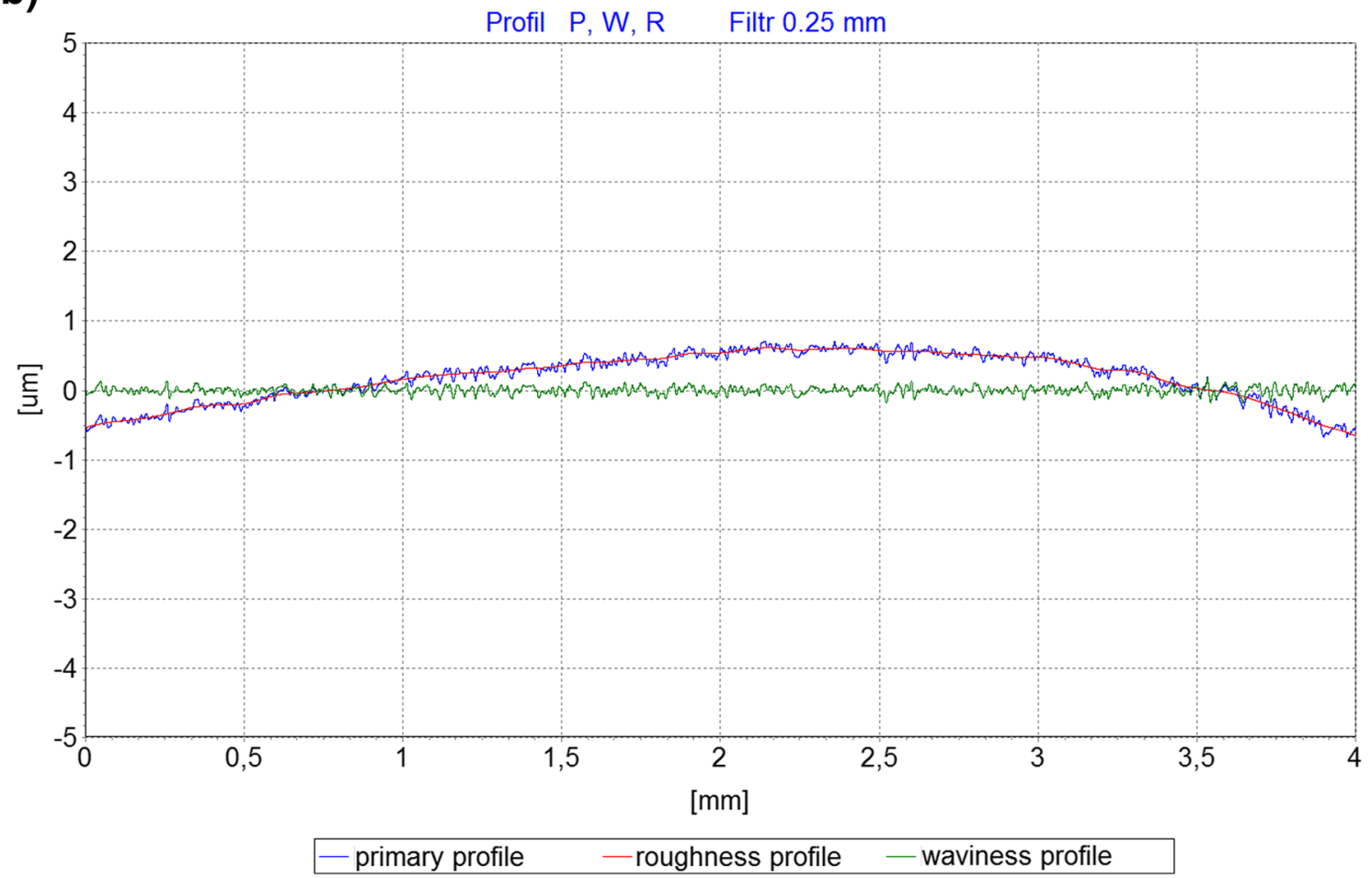

Fig. 5 Profile of flank face of BNDCC composite $\mathbf{a}$ before and $\mathbf{b}$ after grinding process

present in the material, on the basis of the nonoverlapping diffraction line $2 \theta=48.30^{\circ}, d_{\mathrm{hk} 1}=1.88353 \AA$ (101) $2 \theta=84.07^{\circ}, d_{\mathrm{hkl}}=1.14875 \AA$ (201). The residual stresses were calculated only for matrix composite in order to observe influence of reinforcing particles on the stress character in the final material. The residual stress results obtained for the long edge (rake face) and short edge (flank face) are presented in Table 8.

The residual stresses obtained along the short edge after grinding have compressive character. The results 

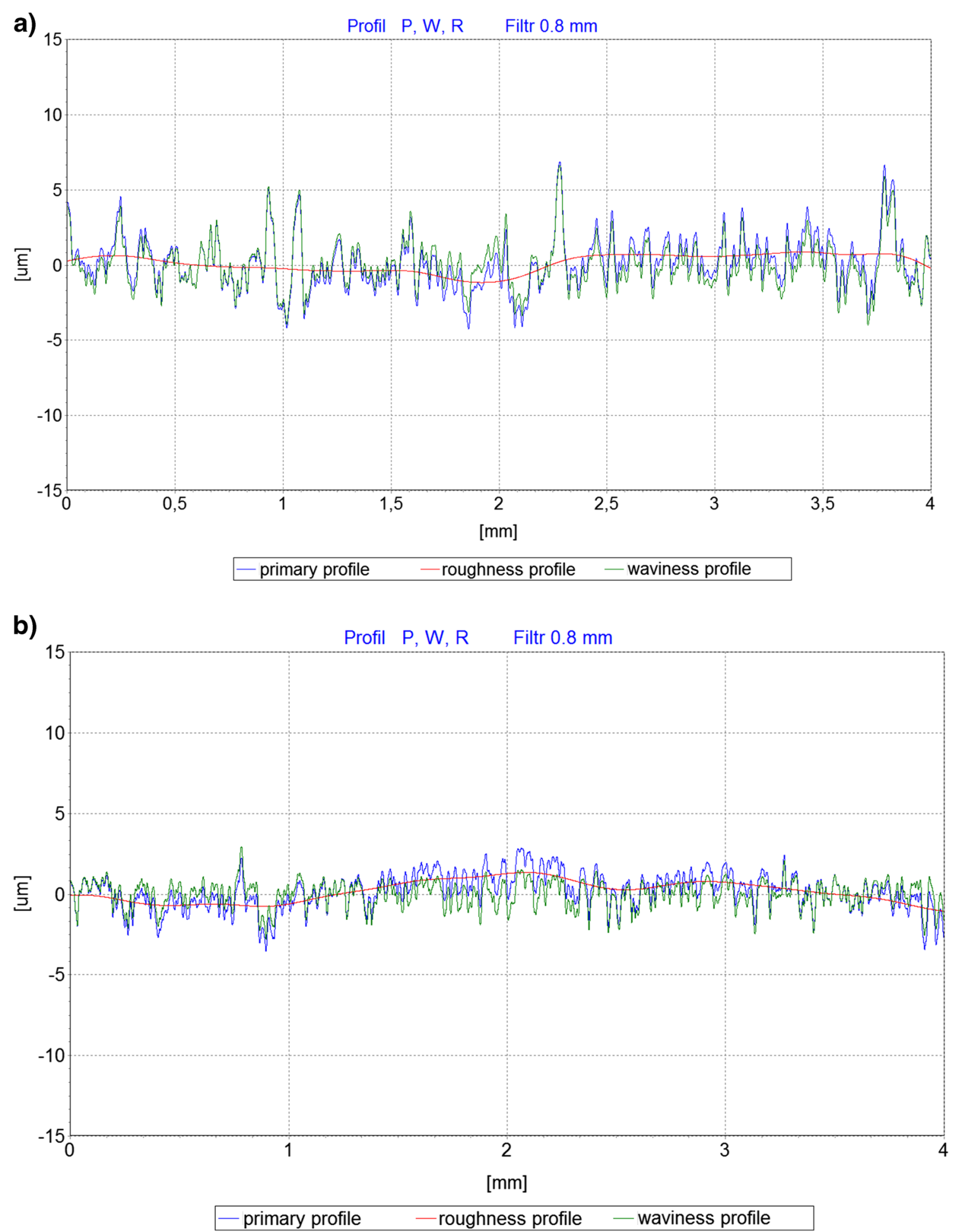

Fig. 6 Profile of edge roughness of flank face of BNDCC before and after grinding process

obtained along the rake face are of different nature. This might be an effect of applied manufacturing technology, especially the EDM machining method. During the EDM machining process, the heat is generated at the contact of the blade/material, leading to a gradient of temperature reaching into the material. The highest temperatures are located on the surface and on the cutting edge of the rake face of material, and the value decreases with distance from it. It follows that the surface layer after the EDM treatment is characterized by a state of tensile stress. 
a)

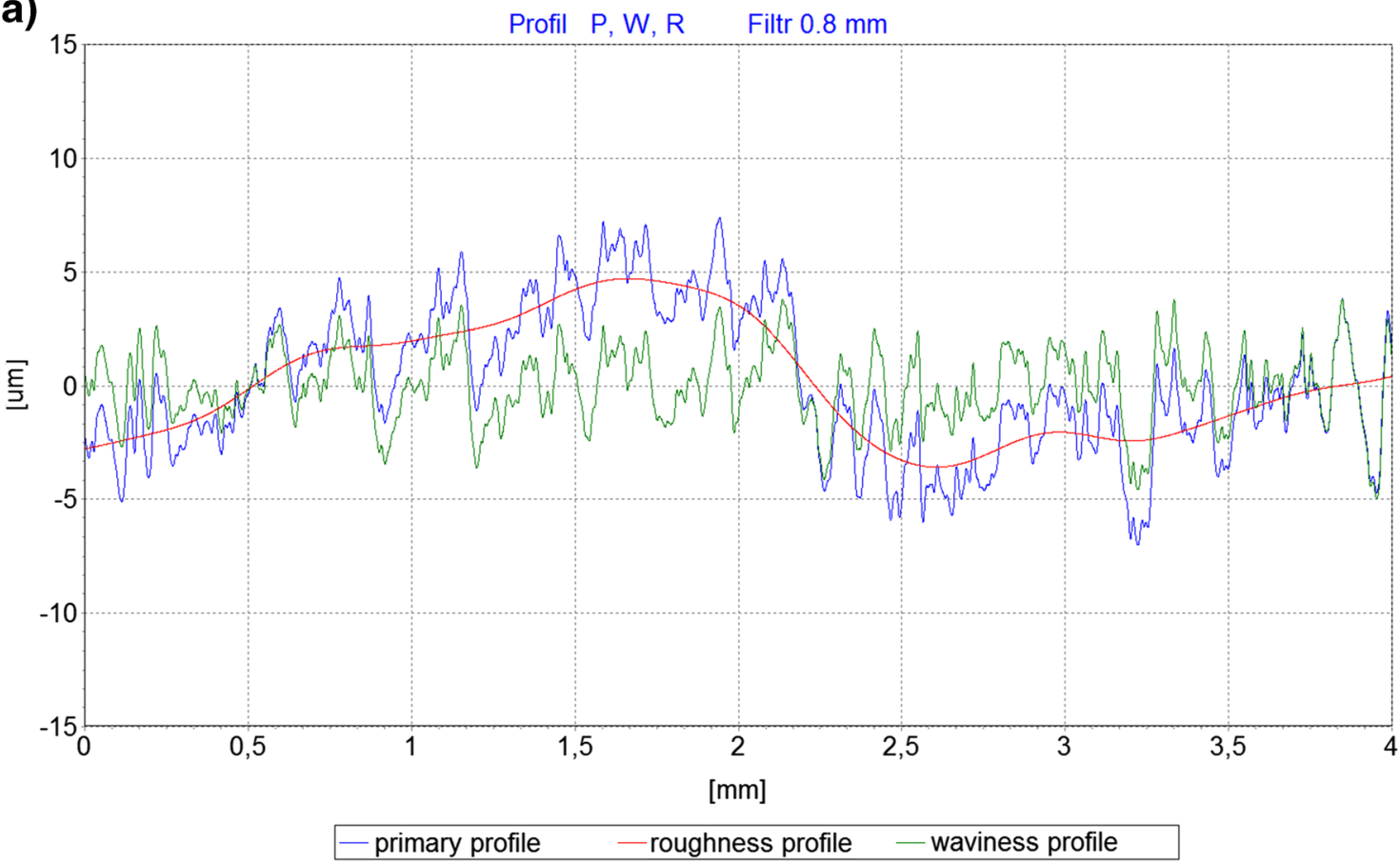

b)

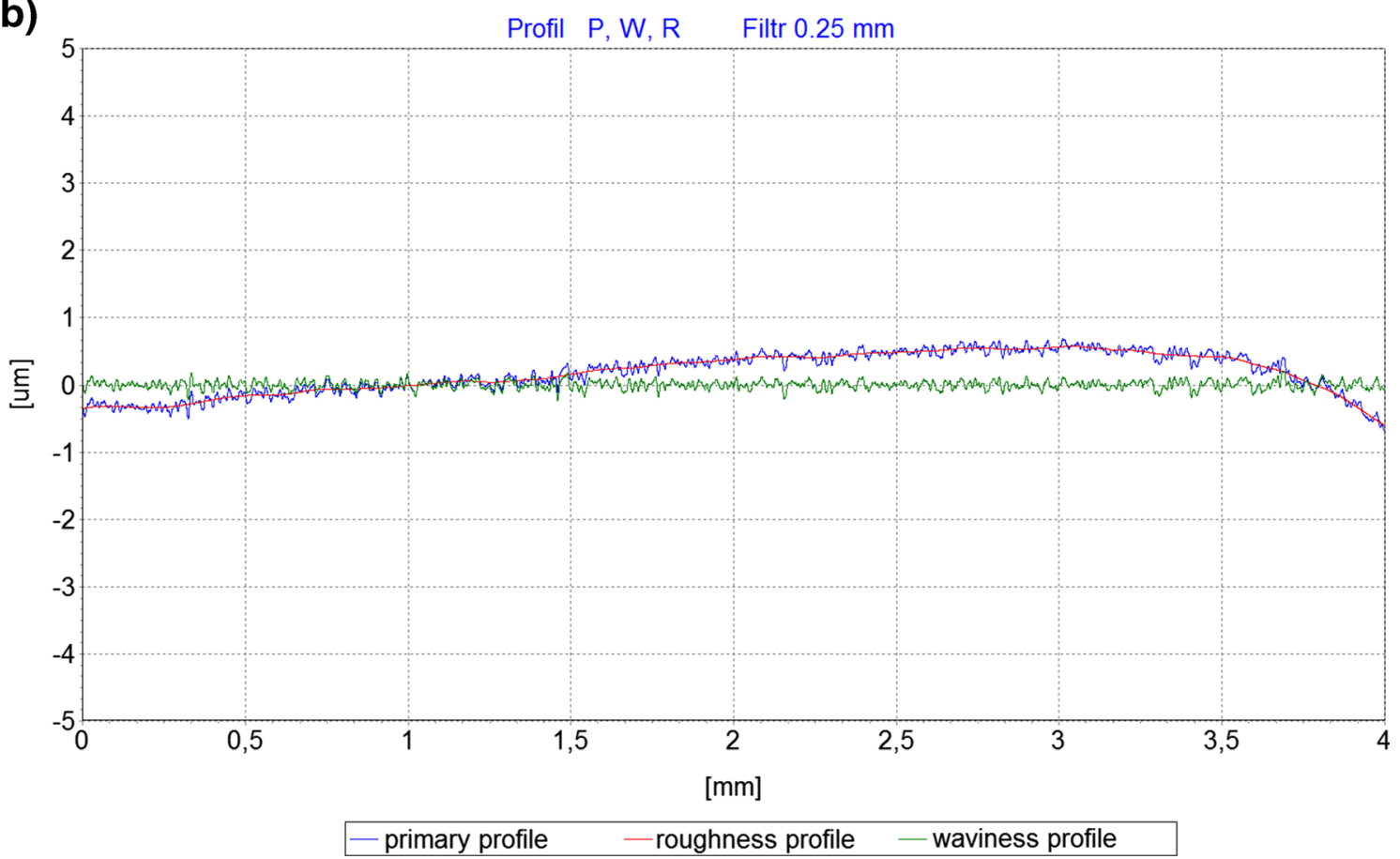

Fig. 7 Profile of flank face of H10S composite $\mathbf{a}$ before and $\mathbf{b}$ after grinding process

Applied grinding removes the top layer of the material and thus exposes the inner layer characterized by the presence of compressive stresses. Obtained results indicate also presence of non-homogeneities in the material. The residual stresses in the reference sample, both before and after grinding process on both surfaces, had compressive nature (Table 9).

\subsection{The topography and microstructure of the BNDCC composite and reference sample H10S surfaces}

The topography results can be explained by the specificity of the grinding process. It is related to the length of the grinding wheel's contact with the material being ground and the different values of the unit pressure of the wheel 


\section{a)}

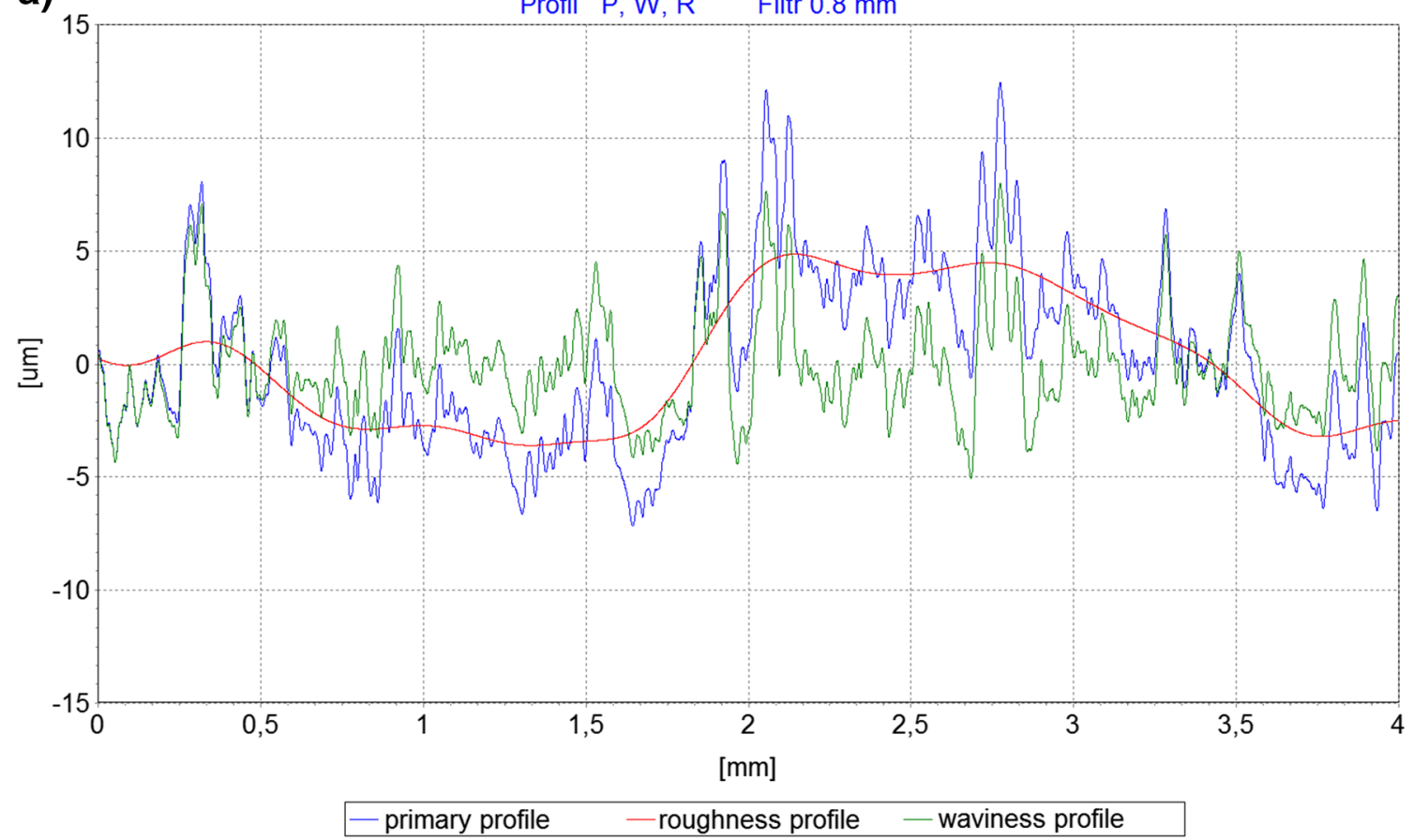

b)

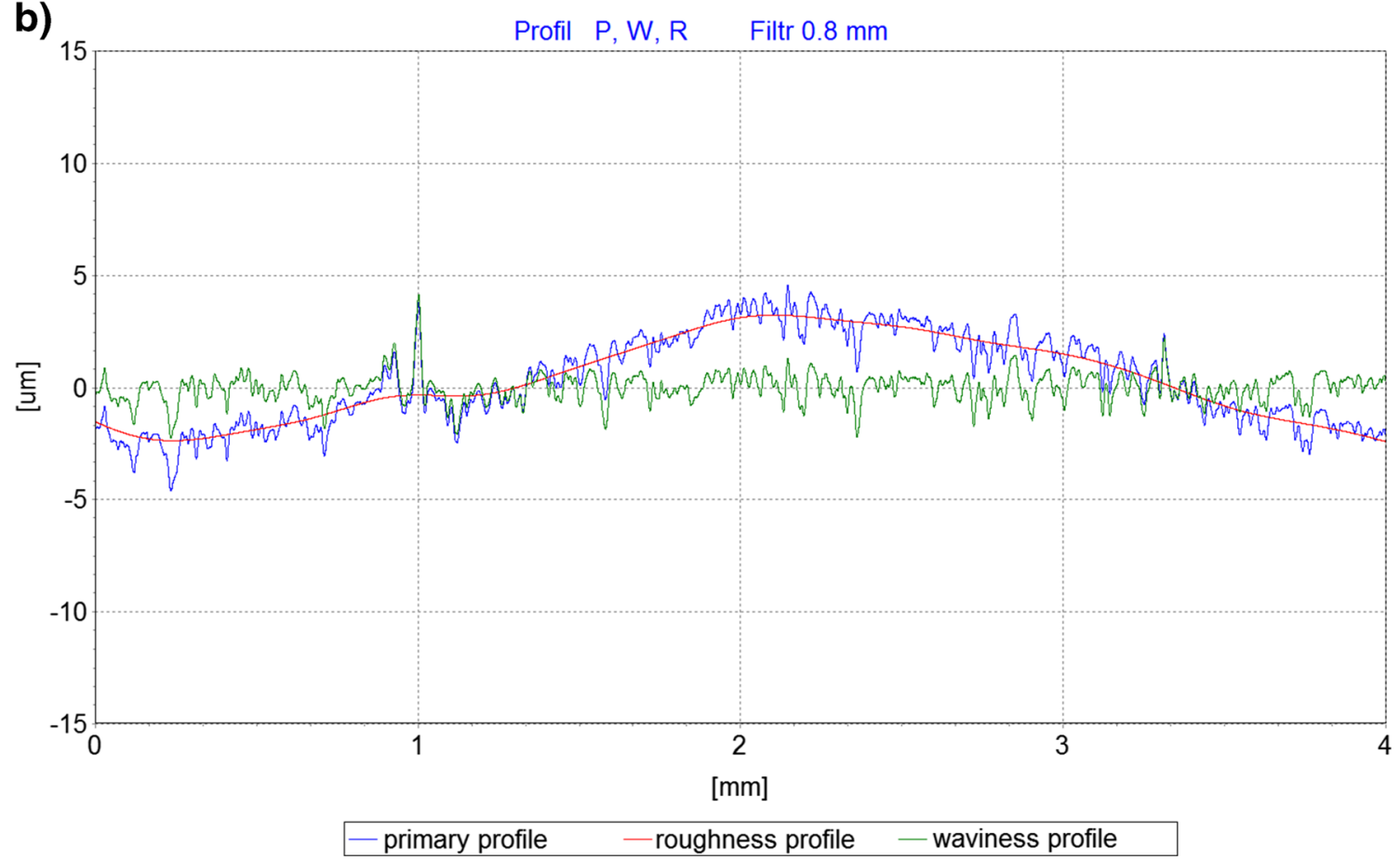

Fig. 8 Profile of edge roughness of H10S composite $\mathbf{a}$ before and $\mathbf{b}$ after grinding process

at the entrance and exit from the material. The edge roughness of the flank and rake face area of the BNDCC and H10S composites, described by roughness parameters $\left(R_{\mathrm{a}}, R_{\mathrm{z}}, R_{\mathrm{t}}\right)$, (Tables 10,11, 12, and 13), had slightly higher values, mainly as a result of the size of the grinding material's contact surface.
Visualization of surface topography of tested materials is presented in Figs. 5, 6, 7, and 8. Using the correlation coefficient as the quotient of $R_{a}$ before and after grinding, expressed as a percentage, it can be stated that the quality of the flank composite of both the BNDCC and the H10S improved significantly, by $2842 \%$ for the BNDCC and 

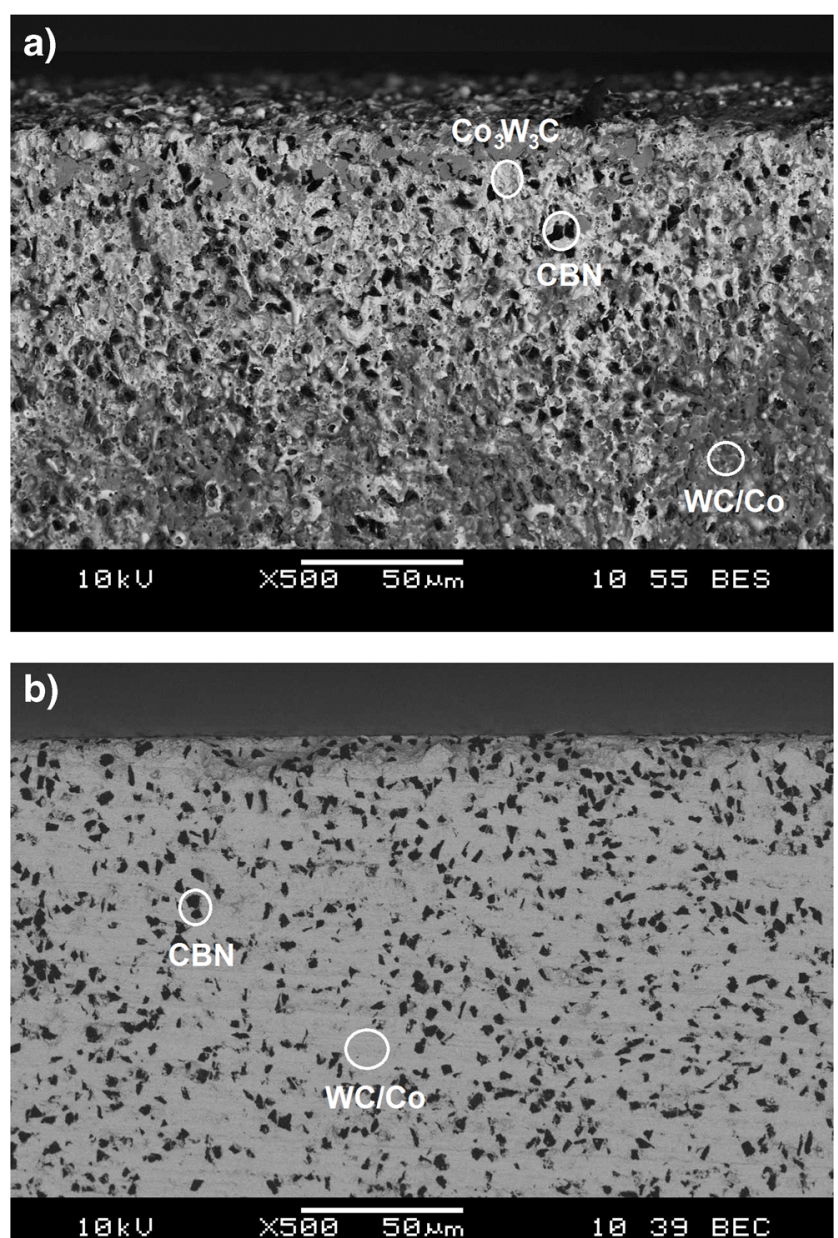

Fig. 9 SEM images of rake face of BNDCC composite $\mathbf{a}$ before and $\mathbf{b}$ after grinding

$2547 \%$ for the H10S. The value of the cutting radius samples of both the BNDCC and H10S composites was slightly higher prior to the grinding process than it was afterwards, at 0.13 and $0.09 \mu \mathrm{m}$, respectively. There was no additional bruising, which indicates that the grinding parameters and methods of securing the samples were selected properly.

The results for the surface roughness of the flank face area and the edge roughness of the BNDCC and H10S composites are shown in Figs. 5, 6, 7, and 8, where the results of the profile analysis are presented. All the samples of the surface roughness parameters were often inferior to the output parameters. Flank face area surface of both, BNDCC composite and samples of the H10S have lower values of the parameter of surface roughness $\left(R_{\mathrm{a}}\right.$, $R_{\mathrm{z}}, R_{\mathrm{t}}$ ) than the rake face area.

Before grinding, microstructures of the samples had visible "white layer" on the edges (Figs. 9a, 10a, 11a, and 12a). The presence of "white layer" results from wire EDM cutting and is created from the $\mathrm{Co}_{3} \mathrm{~W}_{3} \mathrm{C}$ nonstoichiometric compound and cobalt oxide CoO. During
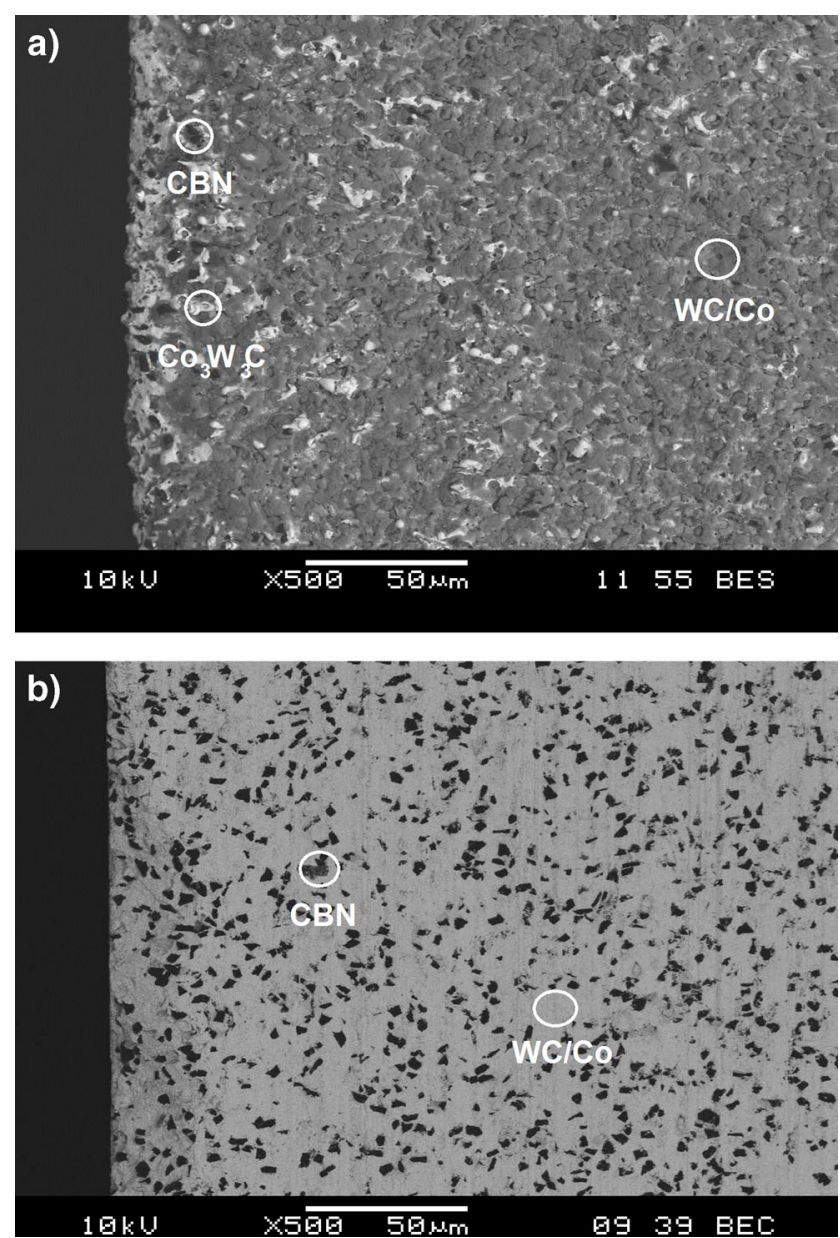

Fig. 10 SEM images of flank face of BNDCC composite $\mathbf{a}$ before and $\mathbf{b}$ after grinding

grinding process, that layer was removed, as was confirmed by X-ray examination (Figs. $7 \mathrm{~b}$ and $8 \mathrm{~b}$ ). The sharp edge of the composite was visible and randomly distributed grains of cubic boron nitride stood out clearly on its surface (Fig. 9b, 10b, 11b, and 12b).

To summarize the research carried out so far, it can be concluded that the proposed conditions for grinding the flank and rake face area of both the BNDCC composite and the H10S reference sample using the diamond wheels with the newly developed ceramic binder were properly selected. The performance parameters of the material removal rate for the grinding were similar, $\left(Q_{w}\right.$ flank face area for the BNDCC $1.40 \times 10^{-2} \mathrm{~mm}^{3} / \mathrm{s}, Q_{w}$ flank face area of $\mathrm{H} 10 \mathrm{~S} 1.46 \times 10^{-2} \mathrm{~mm}^{3} / \mathrm{s}$ ) regardless of the granularity of diamond grinding wheels (D46, D25). In both cases, the self-sharpening phenomenon, involving microchunking provided to form the new sharp microedges, was observed. Measurements of the surface topography of flank face area, rake face area, and of the edge roughness for both the BNDCC and the H10S showed that surface roughness parameters after grinding 

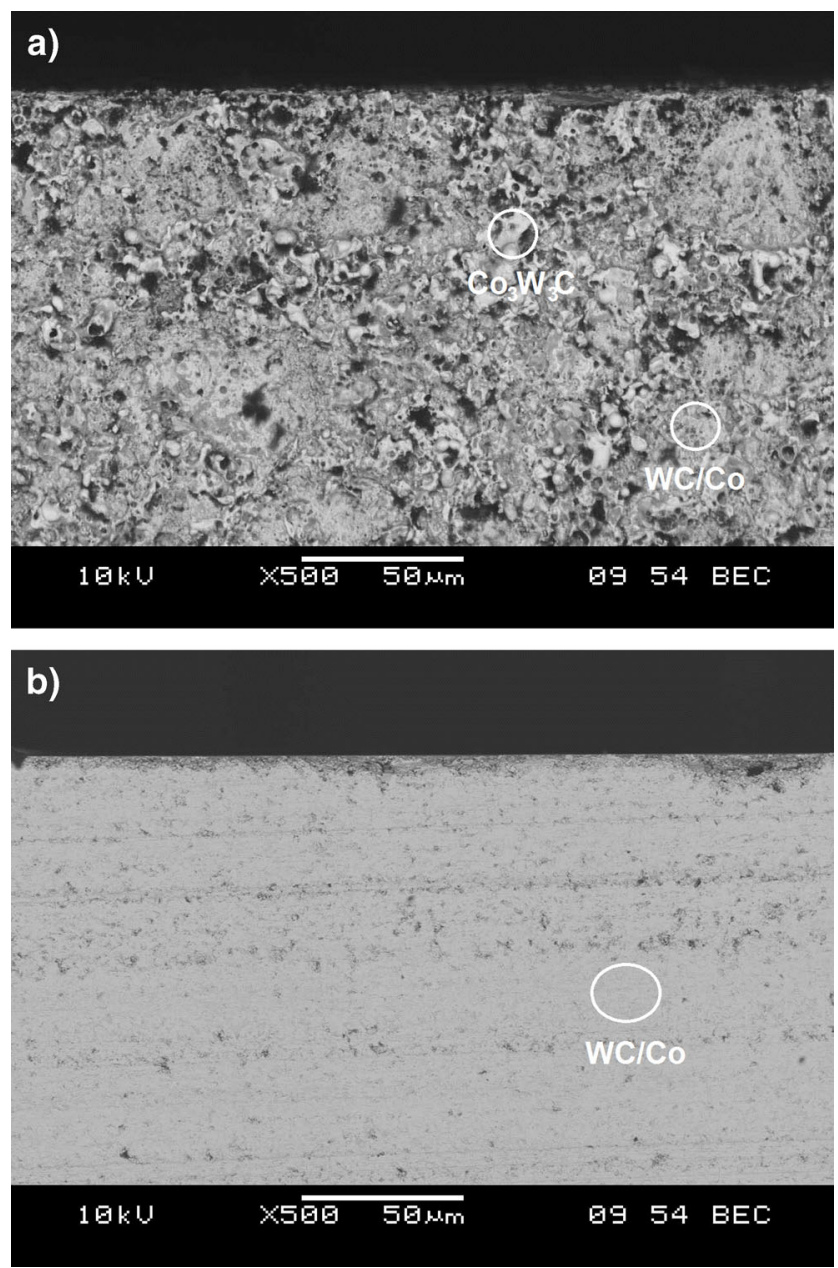

Fig. 11 SEM images of rake face of H10S composite $\mathbf{a}$ before and $\mathbf{b}$ after grinding

of all samples were often inferior to the output parameters. The roughness of the flank face area of both BNDCC and H10S tools had similar values to the roughness of the rake face area. Measured $R_{a}$ of the BNDCC flank face area was $0.040 \mu \mathrm{m}$ and the $R_{a}$ of the H10S flank face was equal to $0.051 \mu \mathrm{m}$, while the roughness of the rake face edge $R_{a}$ of BNDCC area was $0.117 \mu \mathrm{m}$ and the $R_{a}$ of the H10S was $0.101 \mu \mathrm{m}$. This can be explained by the specificity of grinding process, related to the length of contact of grinding wheel with material being ground and the different values of unit pressure at the time of entry into material of the wheel and out of the material. The sharp edge was clearly visible. Cubic boron nitride grains were visible on the composite surfaces. The residual stresses obtained along the short edge after grinding have a compressive character. The results obtained for the rake face display different characters, which might indicate non-homogeneity in the material. In general, the residual stresses in the H10S reference sample have the compressive nature on both the surfaces tested, both before and after the grinding process.
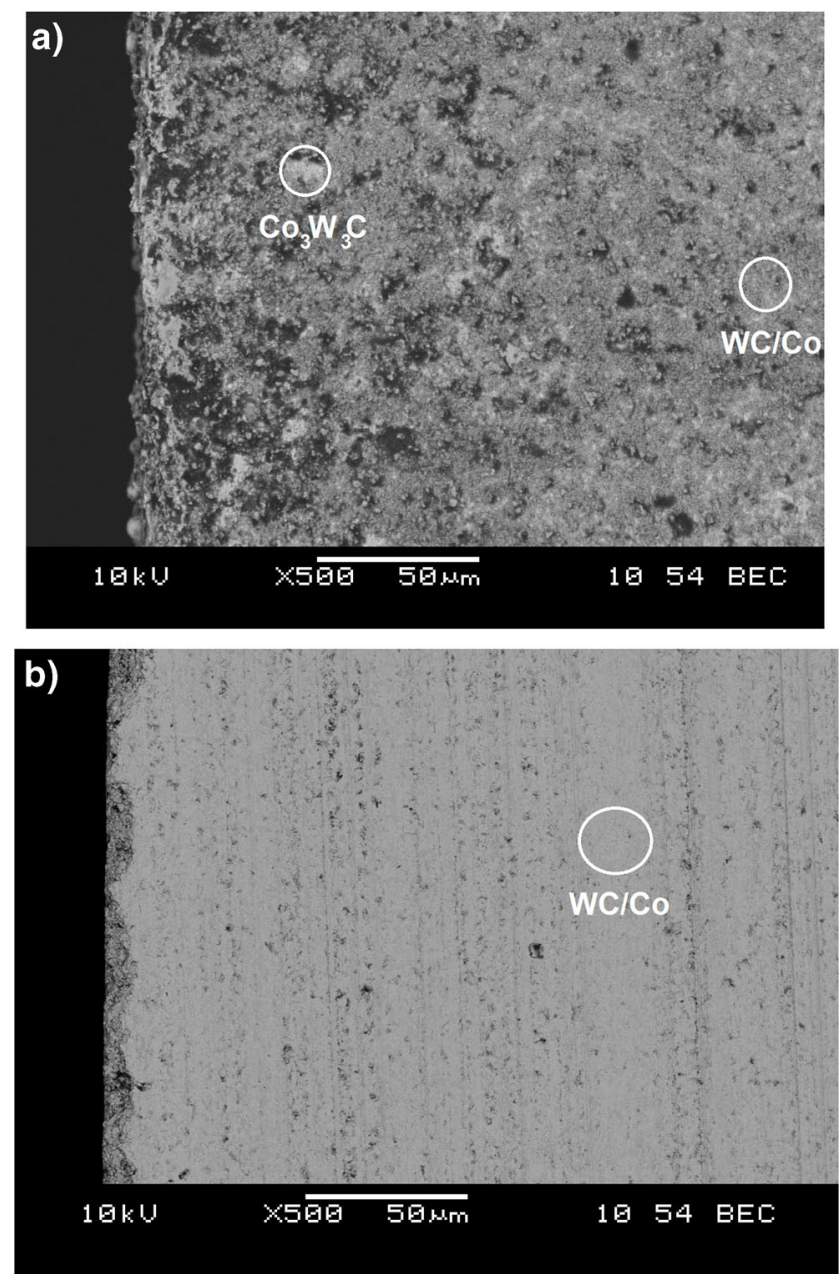

Fig. 12 SEM images of flank face of H10S composite a before and $\mathbf{b}$ after grinding

\section{Conclusions}

Results of performed studies and analyses proved the proper choice of grinding wheel binder material, which enables selfsharpening of the grinding wheel during grinding process, what is very useful phenomenon for proper machining. Analysis of the measured surface topography parameters clearly indicates the significant improvement after grinding in comparison to the state before the grinding process. Selected method of cutting tool manufacturing enforced existence of "white layer" (heat affected zone) on the surface of BNDCC and $\mathrm{H} 10 \mathrm{~S}$ composites before grinding. X-ray studies of that layer indicated the presence of $\mathrm{Co}_{3} \mathrm{~W}_{3} \mathrm{C}$ phase. White layer was removed during the grinding process. It may be stated that binder type and tool work conditions, described in the paper, proved their usefulness in the practical application of grinding process.

Acknowledgments This work was supported by the Applied Research Program Contract No. PBS1/A5/7/2012 "Application of modern BNDCC 
and DDCC composites for cutting tools," financed by The National Centre for Research and Development of Poland.

Open Access This article is distributed under the terms of the Creative Commons Attribution 4.0 International License (http:// creativecommons.org/licenses/by/4.0/), which permits unrestricted use, distribution, and reproduction in any medium, provided you give appropriate credit to the original author(s) and the source, provide a link to the Creative Commons license, and indicate if changes were made.

\section{References}

1. Houy- $\mathrm{G}$ et al (2012) Effect of porosity on the grinding performance of vitrified bond diamond wheels for grinding. PCD Blades; Ceram Int 38:6215-6220. https://doi.org/10.1016/ceramint.2012304.074

2. Jackson MJ, Hitchiner MP (2013) High performance grinding and advanced cutting tools, chapter 2; Springer Science+Business Media New York. https://doi.org/10.1007/978-1-4614-3116-9

3. Kruszewski M, Rosiński M, Grzonka J, Ciupiński Ł, Michalski A, Kurzydłowski KJ (2012) Cu composites - a diamond with a high thermal conductivity produced by PPS. Ceram Mater 64:335-337

4. Rosiński M, Chrzanowski W, Spychalski M, Michalski A (2012) Wpływ parametrów procesu szlifowania na stan powierzchni kompozytu WCCo/diament wytwarzanego metodą PPS. Mater Ceram 64:314-318 (in Polish)

5. Wachowicz J, Michalski A (2014) Trwałość ostrzy skrawających z kompozytów diament/WCCo w obróbce skrawaniem płyty MDF. Mater Ceram 66:10-13 (in Polish)
6. Rosiński M, Michalski A (2012) WCCo/cBN composites produced by pulse plasma sintering method. J Mater Sci 47(20):7064-7071. https://doi.org/10.1007/s10853-012-6532-x

7. Lin K-H, Peng S-F, Lin S-T (2007) Sintering parameters and wear performances of vitrified bond diamond grinding wheels. Int $\mathrm{J}$ Refrac Metals Hard Mater Elsevier 25:25-31

8. Staniewicz-Brudnik B, Baczek E, Skrabalak G (2015) The new generation of diamond wheels with vitrified (ceramic) bonds; book sintering techniques of materials. Chapter 4:53-76

9. Procyk B, Staniewicz-Brudnik B, Majewska-Albin K (2001) Investigations of wettability and reactivity in glass/carbon and glass/ceramic systems, HTC-2000 High Temperature Capillarity, Third International Conference, 19-22 November, Kurashiki, Japan. Transactions of JWRI, 30, Osaka University: 149-154

10. PN-EN ISO 4287:1999 - wersja polska (polish version) Specyfikacje geometrii wyrobów - Struktura geometryczna powierzchni: metoda profilowa - Terminy, definicje i parametry struktury geometrycznej powierzchni

11. Young RA (1993) The Rietveld method. Press, Oxford University

12. Karolus M (2006) Applications of Rietveld refinement in Fe-B-Nb alloy structure studies. J Mater Process Technol 175:246-250

13. Karolus M, Lagiewka E (2006) Structure studies of $\mathrm{Fe}_{81} \mathrm{Nb}_{5} \mathrm{~B}_{14}$ annealed alloys by Rietveld refinement. J Alloys Compd 423:9295

14. Cullity BD (2001) Elements of X-ray diffraction. Prentice-Hall Inc, New Jersey

15. Smithells CJ, Brandes EA (1976) Metal reference book, 5th edn. Butterworths, London, pp 975-980 